
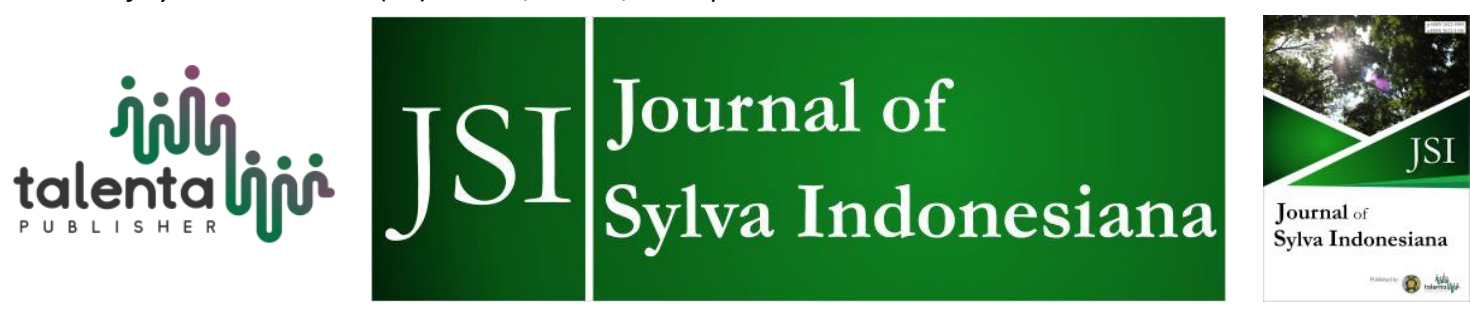

\title{
Vulnerability Study of Coastal Communities in The East Lombok in Facing The Impact of Climate Change
}

\author{
Andi C Ihsan', Tenri Waru ${ }^{2}$ \\ ${ }^{1}$ Major of Forestry, Faculty Agriculture, Mataram University \\ ${ }^{2}$ Major of Communication Science, Mataram University
}

\begin{abstract}
This study aims to assess the level of vulnerability of coastal communities to climate change in East Lombok Regency, by examining exposure, sensitivity, and adaptability in ten coastal villages in East Lombok Regency. This research was conducted in July-November 2015 using a participatory approach. The study method was adopted from the Participatory Rural Appraisal (PRA) method with adjustments for the context of the coastal and marine areas called the Indonesian climate adaptation tools for coastal habitat (I-CATCH). The results of the study showed that most of the villages that were the focus of the implementation of this study had moderate to high levels of vulnerability. The impact of climate disasters experienced was quite burdensome to the community from the physical, social, and economic aspects. Thus, a systematic plan was needed and integrated with existing policies to ensure its implementation in the field.
\end{abstract}

Keyword: Climate Change, Participatory, Vulnerability

Received 21 January 2019| Revised 22 February 2019| Accepted 2 April 2019

\section{Introduction}

Climate change is an undeniable phenomenon that impacts the lives of people of West Nusa Tenggara (WNT) Province. Some climate change indications in this region, such as the shorter rainy season with larger volumes and the increase of extreme weather frequency, have disrupted the growth of food crops in WNT [1].

East Lombok Regency is in the administrative area of West Nusa Tenggara Province. This area is located in the eastern part of Lombok Island with an astronomical position at $116^{\circ}-117^{\circ} \mathrm{E}$ and $8^{\circ}-9^{\circ}$ S. East Lombok Regency has a fairly long coastline, bordering the Java Sea in the north, Alas Strait in the east, Indonesian Ocean in the south, and Central Lombok and North Lombok

\footnotetext{
*Corresponding author at: Mataram University, Jl. Pendidikan No 37 Mataram - Provinsi Nusa Tenggara Barat E-mail address: andi.foresta@unram.ac.id

Copyright (c) 2019 Published by Talenta Publisher p-ISSN: 2622-5093 e-ISSN: 2622-5158 DOI : 10.32734/jsi.v2i1.809 Journal Homepage: http://talenta.usu.ac.id/Jsi
} 
Regency in the west. As an area directly adjacent to the waters, East Lombok has a number of small islands (also called 'Gili' by local people). Based on the Maritime and Fisheries Service of East Lombok Regency, there are 35 gilis in the waters of East Lombok, five of which namely Gili Beleq, Gili Bidara, Gili Maringkik, Gili Ree and Gili Sunut are already inhabited. Since the region is very vulnerable to the effects of climate change, the coastal area and small islands need optimal attention and management support in the regional development planning system.

Based on several studies in the East Lombok regency, the current climate has changed, both in terms of intensity, frequency, and pattern. The coastal area of East Lombok Regency is one of the areas that have the potential to receive the impact of these changes.

This study aims to assess the level of vulnerability, by evaluating the exposure, sensitivity, and adaptability (capacity) of the community in dealing with various symptoms and impacts of climate change. The basic concept to implement this study was a qualitative method using a participatory approach.

\section{Method}

The vulnerability assessment was conducted on 10 coastal villages namely the villages of South Batu Nampar, Jerowaru, Pemokong, Kwang Rundun, Paremas, Sekaroh, Serewe, Wakan, Pandan Wangi, and Ekas Buana, all located in Jerowaru Sub-District. Jerowaru Sub-District is situated in the southern tip of East Lombok and rich in the potential for developing coastal aquaculture.

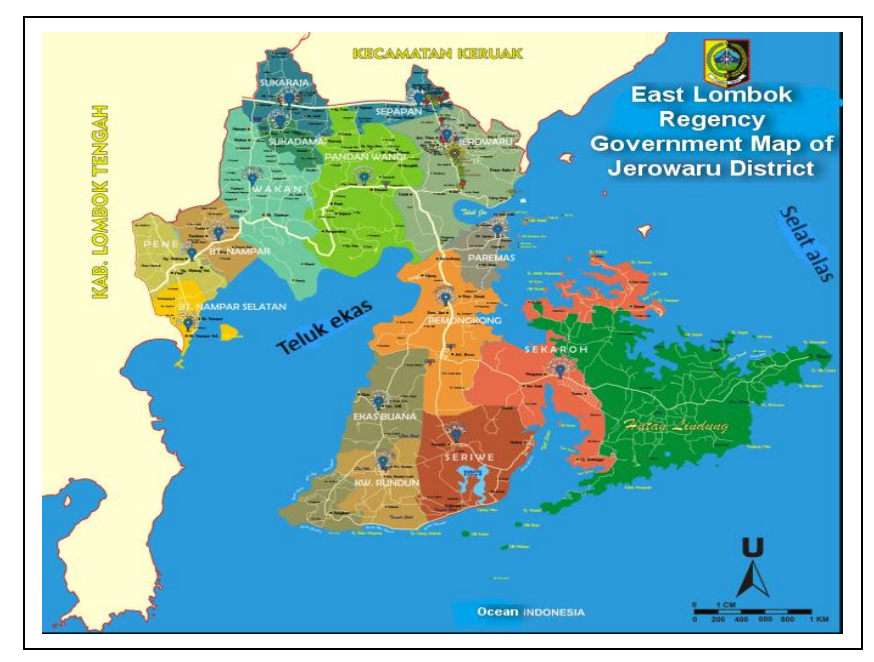

Figure 1 Map of the Jerowaru sub-district in East Lombok Regency

The method of this study was adopted from a Participatory Rural Appraisal (PRA) study with adjustments for the context of coastal and marine areas called the Indonesian Climate Adaptation Tools for Coastal Habitat (I-CATCH) [2]. In this method, researchers assisted 
communities to assess their vulnerability to the effects of climate change and then use the explored information to develop community adaptation plans. Data were obtained using a combination of observation techniques, literature studies, and focus group discussions. Informants were chosen by using purposive sampling technique based on the characteristics developed by [3], with the criteria able to master and understand data, information, or facts of the studied object. The obtained data were descriptively analyzed. Descriptive analysis is defined as a method designed to describe information about actual or temporary conditions that take place [4]-[6]. The stages in this study are described as follows:

Table 1 Stages of implementation of I-CATCH

\begin{tabular}{|c|c|}
\hline $\begin{array}{l}\text { Stage 1. Community Profile } \\
\text { Identification }\end{array}$ & $\begin{array}{l}\text { - Sketch of the village } \\
\text { - Seasonal calendar } \\
\text { - History of community livelihoods }\end{array}$ \\
\hline $\begin{array}{l}\text { Stage } 2 . \quad \text { Recognize } \\
\text { climate conditions }\end{array}$ & $\begin{array}{l}\text { - Climate patterns } \\
\text { - Weather conditions } \\
\text { - History of events }\end{array}$ \\
\hline $\begin{array}{l}\text { Stage 3. Recognize the } \\
\text { problem of climate impacts }\end{array}$ & - Recognize the impacts and identify problems \\
\hline $\begin{array}{l}\text { Stage } 4 \text {. Assessment of the } \\
\text { people's adaptability }\end{array}$ & - Assessing community adaptability \\
\hline $\begin{array}{l}\text { Stage 5. Assessment of the } \\
\text { level of vulnerability }\end{array}$ & $\begin{array}{l}\text { - The presentation of the source person of the East } \\
\text { Lombok Marine and Fisheries Service } \\
\text { - Participants conducted the assessment }\end{array}$ \\
\hline $\begin{array}{l}\text { Stage } 6 . \text { Development of a } \\
\text { community/village } \\
\text { adaptation plan }\end{array}$ & $\begin{array}{l}\text { - Determine the main problem } \\
\text { - Set goals } \\
\text { - Map the strengths, weaknesses, opportunities, and } \\
\text { obstacles } \\
\text { - Determine who, when, stages of the activity, } \\
\text { stakeholders involved in the activity, and the } \\
\text { expected support. }\end{array}$ \\
\hline
\end{tabular}

\section{Results and Discussion}

The analysis result showed that in general, the livelihoods of community in the study area were farming and raising livestock. Farmers plant rice with a gora (gogo rancah) system in the rainy season, while in the dry season some farmers grow Virginia tobacco. According to the interviews with local leaders, the agricultural activities have been going on for 40 years. To support this agricultural business, farmers built embung, a water reservoir, usually on the size of 0.5 - 2 hectares. In rainy season, the embung is used to hold rainwater that will become channeled into the rice fields in dry season.

Focus group discussions were also conducted during the research. The results informed that the community did realize that there were the changes in weather conditions in the village, in particular on the seas. The changing led to various impacts on the condition of natural resources, property, infrastructure, and people's lives. The identified impacts as follows: 
1. The increase in air temperature resulted in the reduction of agricultural yield due to lack of water.

2. The increase in seawater temperature was a consequence of the increase in the air temperature. The increase in seawater temperature resulted in the diminishing catches because fish prefer being in deep waters where temperatures were relatively cooler than in shallow waters.

3. Rainfall increase with greater intensity resulted in crop failures.

4. The speeding wind caused the fish traps to damage and prevented the fishermen to go to the sea.

5. Sea level rise was very influential on the condition of the salt and fish ponds because they were more susceptible to damage.

6. The increase in the size of the ocean waves resulted in fishermen not being able to go to the sea, thus reducing their income.

7. Increasing current velocity resulted in Floating Net Cages (FNC) and nets (and other fishing gears) being easily washed away

Considering the impacts above, vulnerability study needed to be done. One of the factors analyzed was the identification of the level of exposure to changes in climate conditions that occurred in each village. The components of changes in climate conditions and their scope for people's lives were described before the assessment being conducted. The details about the analysis of exposure levels can be seen in Table 2:

Table 2 Level of Village Exposure

\begin{tabular}{|c|c|c|c|}
\hline Value & Description & Explanation & $\begin{array}{c}\text { Number } \\
\text { of } \\
\text { Villages }\end{array}$ \\
\hline $\begin{array}{l}\text { LOW } \\
\text { (1) }\end{array}$ & $\begin{array}{l}\text { A small portion of } \\
\text { natural resources is } \\
\text { affected by changes } \\
\text { in } \\
\text { conditions or some } \\
\text { individuals whose } \\
\text { livelihood depends } \\
\text { on } \\
\text { conditions climate }\end{array}$ & $\begin{array}{l}\text { The community was experiencing: } \\
\text { - The duration of the monsoon and the } \\
\text { rainy season remains the same or } \\
\text { only shifts slightly, the signs of the } \\
\text { arrival of the season remain the same, } \\
\text { the ability of the community to predict } \\
\text { the season is still reliable } \\
\text { - Only a few sources of income depend } \\
\text { on climatic conditions } \\
\text { - Events regarding bad weather which } \\
\text { damage the property and life- } \\
\text { threatening rarely occur in the last } 10 \\
\text { years } \\
\text { There is no or only a small amount of } \\
\text { land inundated by sea water due to } \\
\text { high tides or sea level rise }\end{array}$ & 1 Village \\
\hline $\begin{array}{l}\text { MEDIUM } \\
\text { (2) }\end{array}$ & $\begin{array}{l}\text { About half of the } \\
\text { community or } \\
\text { natural resources are } \\
\text { affected by changes } \\
\text { in climate }\end{array}$ & $\begin{array}{l}\text { The community was experiencing: } \\
\text { - The duration of the rainy season } \\
\text { changes, shifts several days to } \mathbf{1} \\
\text { month, the signs of the arrival of the } \\
\text { season are partly different, the ability }\end{array}$ & 1 Village \\
\hline
\end{tabular}




\begin{tabular}{|c|c|c|c|}
\hline & $\begin{array}{l}\text { conditions and or } \\
\text { half of the } \\
\text { population of the } \\
\text { village whose } \\
\text { livelihood depends } \\
\text { on climate } \\
\text { conditions }\end{array}$ & $\begin{array}{l}\text { to predict the season is only partially } \\
\text { reliable. } \\
\text { - } \frac{\text { Some sources of income depend on }}{\text { climatic conditions }} \\
\text { - Events regarding bad weather which } \\
\text { damage the property and life- } \\
\text { threatening seldom occur in the last } \\
10 \text { years } \\
\text { - The inundated area by seawater due to } \\
\text { high tides or sea level remains the } \\
\text { same every year }\end{array}$ & \\
\hline $\begin{array}{l}\text { HIGH } \\
\text { (3) }\end{array}$ & $\begin{array}{l}\text { Most of all natural } \\
\text { resources are } \\
\text { affected by changes } \\
\text { in climate } \\
\text { conditions and or } \\
\text { almost all villagers } \\
\text { whose livelihoods } \\
\text { depend on climate } \\
\text { conditions }\end{array}$ & 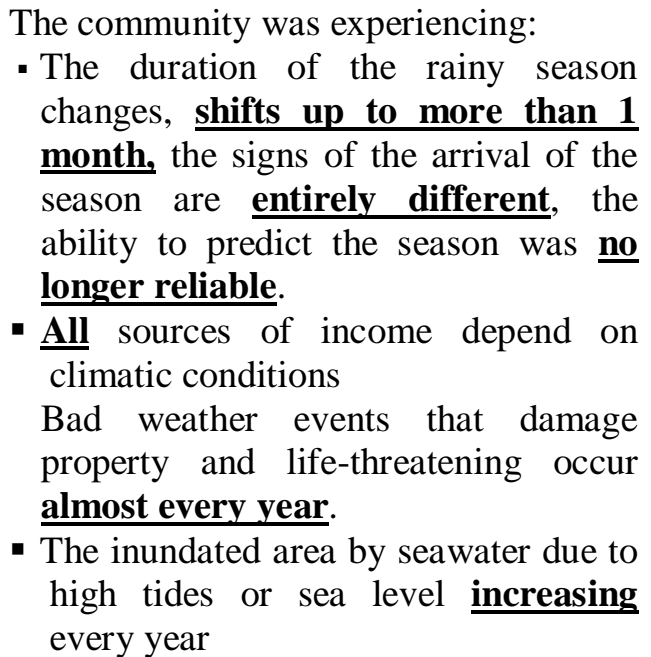 & $\begin{array}{c}8 \\
\text { Villages }\end{array}$ \\
\hline
\end{tabular}

As presented in Table 2, the level of exposure in each village was quite high. Eight villages were influenced by the impact of the changing of seasonal conditions. The impacts were caused by several factors such as the physical condition of the region and evel of community dependence on the resources itself.

This study also focused on the level of community sensitivity to the effects of climate change that occurred in each village. Conceptually, the sensitivity is the extent to which communities and resources are sensitive or can be affected if climate conditions change such as air temperature and evaporation [7]. Therefore, sensitivity is an assumption of impact based on experience and knowledge possessed by the community. To assist in the process of identifying these sensitivity levels, we used a table of vulnerability ranges which was adopted by the ICATCH module [2]. The details are described in Table 3:

Table 3 The range of public sensitivity

\begin{tabular}{lllll}
\hline \multicolumn{1}{c}{ Effects of climate change and bad } & \multicolumn{3}{c}{ The Range of sensitivity } \\
weather
\end{tabular}




\begin{tabular}{lllcc}
$\begin{array}{l}\text { Effect of changes in climate } \\
\text { conditions on natural resource } \\
\text { fisheries (not causing damage to } \\
\text { coral reefs, mangroves, etc) }\end{array}$ & Small & Moderate & Large \\
\hline $\begin{array}{l}\text { Bad weather events causing damage } \\
\text { and accidents in the last 10 years }\end{array}$ & Seldom & Often & $\begin{array}{c}\text { Frequently } \\
\text { (almost every year) }\end{array}$ \\
\hline $\begin{array}{l}\text { Effect of changes in overall climate } \\
\text { conditions }\end{array}$ & LOW & MEDIUM & HIGH \\
\hline
\end{tabular}

According to the sensitivity range table above, we can conclude that of the 10 villages, 8 villages have moderate sensitivity levels (Table 5) and 2 villages have high sensitivity levels, namely Ekas Buana and Paremas. It showed that most areas were greatly affected by changes in seasonal conditions.

The results of the level of exposure and sensitivity analysis were tabulated using the potential impact matrix (Table 4). The table provides information on whether climate change has a high, medium or small potential impact.

Table 4 Potential Impact Matrices

\begin{tabular}{cccc}
\hline EXPLANATION & \multicolumn{3}{c}{ SENSITIVITY } \\
\cline { 2 - 4 } & Almost none & Moderate & $\begin{array}{c}\text { Severe/high } \\
(\mathbf{2})\end{array}$ \\
\hline $\begin{array}{c}\text { Small to none } \\
(\mathbf{1})\end{array}$ & Small & Small & Medium \\
A few & & Medium & High \\
$\begin{array}{c}(\mathbf{2}) \\
\text { Almost all } \\
(\mathbf{3})\end{array}$ & Small & High & High \\
\hline
\end{tabular}

To provide comprehensive information regarding the implementation of the vulnerability study of coastal communities in East Lombok Regency, we also conducted the analysis of community's ability to deal with climate change that occurred in each village. The parameters were based on a combination of ideal capacity characteristics that were constructed by the community themselves and juxtaposed with the ideal adaptation frame of reference prepared in I-CATCH guidelines, some of which include:

1. The community had a common sense of mutual cooperation, had a leader and several people who worked for the interests of the village, the habit of deliberation to make joint plans and good values in managing the environment.

2. The community had the skill, ability, and cooperation and strong motivation to overcome changes in climate conditions for income sources, including by overcoming bad weather that resulted in property damage and life-threatening conditions.

3. The community was able to build cooperation and good relations with outside parties (NGOs, the private sector, regional governments) and conducted collaborative activities. 
4. Healthy neighborhoods, diverse natural resources, and healthy and sufficient water sources.

5. Having knowledge and experience in dealing with previous environmental changes.

The results of the analysis showed that the community was dominated by moderate adaptability to climate change in each village. These results indicating that although the level of exposure was quite high, the community had begun to prepare themselves by making various efforts such as forming social groups (banjar, farmer groups, fishermen groups, etc.) to strengthen their social relations. On the other hand, to improve the economy the community had also built alternative businesses so that they did not depend solely on just one source of income (trading, artisan, food stalls, tour guides, etc.).

Furthermore, the synthesis process of the level of exposure, sensitivity, and adaptability will provide an overview of the level of vulnerability of the community to the effects of changes in climate conditions (seasonal patterns), weather, and disaster events in each village. The results of the study of the level of vulnerability in the ten villages are described in the following table.

Table 5 Community vulnerability analysis in East Lombok Regency

\begin{tabular}{|c|c|c|c|c|c|}
\hline Village & Main Threat & $\begin{array}{c}\text { Adaptability } \\
\text { Level }\end{array}$ & $\begin{array}{c}\text { Exposure } \\
\text { Level }\end{array}$ & $\begin{array}{l}\text { Sensitivity } \\
\text { Level }\end{array}$ & $\begin{array}{c}\text { Vulnerability } \\
\text { Level }\end{array}$ \\
\hline Batu & Tidal flood & Moderate & High & Moderate & Moderate \\
\hline Nampar & Flood and & & & & \\
\hline Selatan & landslide & & & & \\
\hline & Tornado & & & & \\
\hline Jerowaru & $\begin{array}{l}\text { Abrasion } \\
\text { Cannot go to sea }\end{array}$ & Moderate & High & Moderate & Moderate \\
\hline Pemongkong & $\begin{array}{l}\text { Embankment } \\
\text { damaged }\end{array}$ & Moderate & High & Moderate & Moderate \\
\hline $\begin{array}{l}\text { Kwang } \\
\text { Rundun }\end{array}$ & $\begin{array}{l}\text { Cannot go to sea } \\
\text { Abrasion } \\
\text { Crop failures }\end{array}$ & Moderate & High & Moderate & Moderate \\
\hline Paremas & $\begin{array}{l}\text { Abrasion } \\
\text { Tornado }\end{array}$ & Low & High & High & High \\
\hline Sekaroh & $\begin{array}{l}\text { Crop failures } \\
\text { Abrasion }\end{array}$ & Moderate & High & Moderate & Moderate \\
\hline Serewe & $\begin{array}{l}\text { Abrasion } \\
\text { Crop Failures }\end{array}$ & Moderate & Low & Moderate & Low \\
\hline Wakan & $\begin{array}{l}\text { Tornado } \\
\text { Drought }\end{array}$ & Moderate & Moderate & Moderate & Moderate \\
\hline $\begin{array}{l}\text { Pandan } \\
\text { Wangi }\end{array}$ & $\begin{array}{l}\text { Fisheries yield } \\
\text { decreases } \\
\text { Abrasion }\end{array}$ & Moderate & High & Moderate & High \\
\hline Ekas Buana & $\begin{array}{l}\text { Abrasion } \\
\text { Fisheries }\end{array}$ & Moderate & High & High & Moderate \\
\hline
\end{tabular}


The table 5 illustrated that out of 10 villages there were 2 villages that had a high level of vulnerability, 7 villages had a moderate level of vulnerability and only 1 village had a low level of vulnerability. This showed that changes in climate conditions had an impact on the community's living systems, including on the physical aspects of economic and social-cultural facilities and infrastructure.

The situation had received various responses from the community. They diversified their livelihoods or formed local social groups in order to strengthen their relationships. However, we need to maximize the efforts in dealing with the impact of the occurred changes.

Considering the situation, we provided assistance the community through focus group discussions to identify the strengths, weaknesses, opportunities, and challenges they faced in responding to changes that occur. As a result, it can be illustrated that the community was able to formulate several possible action plans to be carried out at the local level with the aim of minimizing the negative impacts of these changes based on the characteristics of the resources in each village. In general, the formulation of the action plan was prepared as follows:

1. Strengthening the capacity and institutional groups of fishermen

2. Making semi-permanent slopes to withstand abrasion rates

3. Planting mangroves along the shoreline in each village

4. Moving rocks and dredging the bottom of the beach so the boat no longer stuck due to shallowness and dryness when the water receded

5. Diversification of fishing gear.

6. Moving the location of the Floating Net Cages (FNC) to a place that is protected from waves and strong winds.

7. Repairing the pier road and lights

8. Replanting the environment

9. Counselings to increase the community's awareness and skills

The action plan must be integrated into the regional planning systems as one of the institutional and policy instruments that can guarantee its implementation in the field [8]. According to [9] stated that institutional not only in the terms of institutions/organizations or hardware, but also software such as rules, norms, cognitive-culture, working mechanisms, and the magnitude and distribution of authorities. With the guarantee of these institutions, the program intervention that will be carried out can be predicted [10].

\section{Conclusion}

Changes in the characteristics and climatic conditions of each village had an impact on the physical, social, and economic conditions of the community. The capacity of community to deal with these impacts was low so that resulted in a high level of community vulnerability to the 
effects of changing climate conditions. Various efforts conducted by community to adapt of changes in climate conditions. However, these efforts need to be optimized due to the impact of changing seasonal conditions was not comparable to the adaptability of the community. Thus, a systematic plan is needed and integrated with existing policies to ensure its implementation in the field.

\section{REFERENCES}

[1] J. Butler, D.G.C. Kirono, J. Katzfey, and K. Nguyen, Climate Adaptation Strategies for Rural Livelihoods in West Nusa Tenggara Province, Report CSIRO_AusAID, 2009.

[2] P.R. Siregar, Indonesia Climate Adaptation Tool for Coastal Habitats, USAID IMACS : Indonesia, 2012.

[3] B. Bungin, Analisis Data Penelitian Kualitatif, Radja Grafindo Persada, Jakarta, 2003.

[4] C.G. Sevilla et al, Pengantar Metode Penelitian, dalam Alimudin Tuwu dan Alam Syah (penerjemah), UI Press, Jakarta, 1993.

[5] Sugiyono, Metode Penelitian Kunatitatif Kualitatif dan R\&D, Alfabeta, Bandung, 2008.

[6] D. Mulyana, Metodologi Penelitian Kualitatif, PT Remaja Rosda Karya Offset, Bandung, 2010.

[7] IPCC, Climate Change: The Physical Science Basis, Contribution of Working Group (WG) 1 to the Fourth Assessment Report of the (IPCC), Cambridge University Press, Cambridge, UK, and New York, pp. 273-313, 2012.

[8] Dunn, N. William, Analisis Kebijakan Publik, Gadjah Mada University Press, Yogyakarta, 2003.

[9] W.R. Scott, Institutions and Organizations: Ideas and Interests, 3rd ed., Sage Publications, Los Angeles, 2008.

[10] W. Kasper, M.E. Streit, Institutional Economics, Social Order and Policy, Edward Elgar, Cheltenham, UK and Northampton, MA USA, 1998. 